\title{
Identification of Priority Areas for Ecological Restoration in Eastern Pará, Brazil
}

Tatiane Camila Martins Silva ${ }^{1}$ (1) 0000-0001-7852-8735

Ima Célia Guimarães Vieira ${ }^{1}$ (D) 0000-0003-1233-318X

\begin{abstract}
This study aimed to identify priority areas for the passive restoration of the Arauaí river basin, municipality of Moju, Pará, using a multicriteria model. This basin is located in a region with intense land use dynamics and expansion of oil palm cultivation, and with high forest loss and fragmentation. The Weighted Linear Combination method was used, with the aggregation of five criteria (Natural Erosion Vulnerability, Potential Land Use and Cover to Passive Restoration, Proximity to the Primary Forest, Forest cover deficit in PPAs, and Distance from Roads and Highways). This analysis allowed to evaluate different biophysical classes and types of land use that affect the selection of areas for restoration. A total of $207.82 \mathrm{~km}^{2}$ of priority areas for passive restoration were identified in the studied basin, with about $80 \%$ of its priority areas having medium to very high priority. The final map generated proved to be a useful instrument in the environmental management of restoration plans in the Amazon watershed.
\end{abstract}

Keywords: multicriteria analysis, land use, forest cover, natural regeneration.

\section{INTRODUCTION AND OBJECTIVES}

The historical process of Amazonian occupation by large agricultural enterprises resulted in intense spatial and structural changes in the regional landscape (Toledo et al., 2015). Reduction in natural forest areas is a clear consequence of the influence of economic activities, which contributes to the increase of forest fragmentation and biodiversity loss in this region. In eastern Pará, intense occupations and changes in land use have led to the conversion of about $65 \%$ of the existing original primary forest (Almeida \& Vieira, 2010) and the formation of secondary forests that dominate nearly $35 \%$ of the deforested areas (INPE, 2014). The Arauaí river basin, located in the municipality of Moju, is relevant in the context of the land use changes due to its insertion in the expansion zone of oil palm cultivation (Elaeis guineensis Jacq.) in the State of Pará. This basin is subject to intense pressures on its natural resources and land use (Almeida \& Vieira, 2014), dominated by different agricultural uses, isolated fragments of native vegetation, secondary vegetation, and areas under degradation process (Silva et al., 2016). Ongoing degradation of this region leads to the increasing fragmentation, isolation and reduction of the forest remnants (Almeida et al., 2020).

In a scenario of high rates of deforestation and forest fragmentation, Amazon faces the challenge of establishing the restoration of 4.8 million hectares by 2050 (Brasil, 2017). To achieve this goal, it is necessary to adopt strategies and test methodologies for prioritizing the areas to be restored. In this regard, the deforested areas in the Amazon, occupied largely by secondary vegetation and pastures at different stages of degradation (INPE, 2014), have high potential for natural regeneration, which is seen as major passive restoration strategies based in a process of natural succession with the least human intervention (Chazdon, 2008; Holl \& Aide, 2011).

In recent years, much attention has been given to the methodologies that seek to determine priority areas for the adoption of restoration practices (Chazdon \& Laestadius, 2016). Thus, multi-criteria analysis have been used by several authors, focusing on prioritizing areas for forest restoration (Francisco et al., 2008; Orsi \& Geneletti, 2010; Valente et al., 2017) adding criteria that represent the biophysical characteristics of the landscape.

\footnotetext{
${ }^{1}$ Museu Paraense Emílio Goeldi, Belém, PA, Brasil
} 
This study applies an advanced analysis technique with Geographic Information System (GIS) to support decisionmaking and to identify potential priority areas for passive restoration in the Arauaí river basin, municipality of Moju, State of Pará.

\section{MATERIALS AND METHODS}

\subsection{Study area}

The Arauaí river basin is located in the municipality of Moju, northeastern region of Pará (Figure 1) and has a surface area of $465.82 \mathrm{~km}^{2}$, representing about $5.12 \%$ of the municipality. The basin is within the oil palm production zone in Pará, a region that presents the most appropriate climatic conditions for oil palm cultivation in Brazil (Ramalho Filho et al., 2010).

The Arauaí River constitutes a sub-basin of the river Moju (Middle Moju), situated in its right margin. The surrounding region has a hot and humid climate with average monthly temperatures of $25^{\circ} \mathrm{C}$ to $27^{\circ} \mathrm{C}$. The rainfall varies between 2,000 to $3,000 \mathrm{~mm} /$ year, and the rainy season is from January to June. Relative humidity is about 85\% (IDESP, 2013).
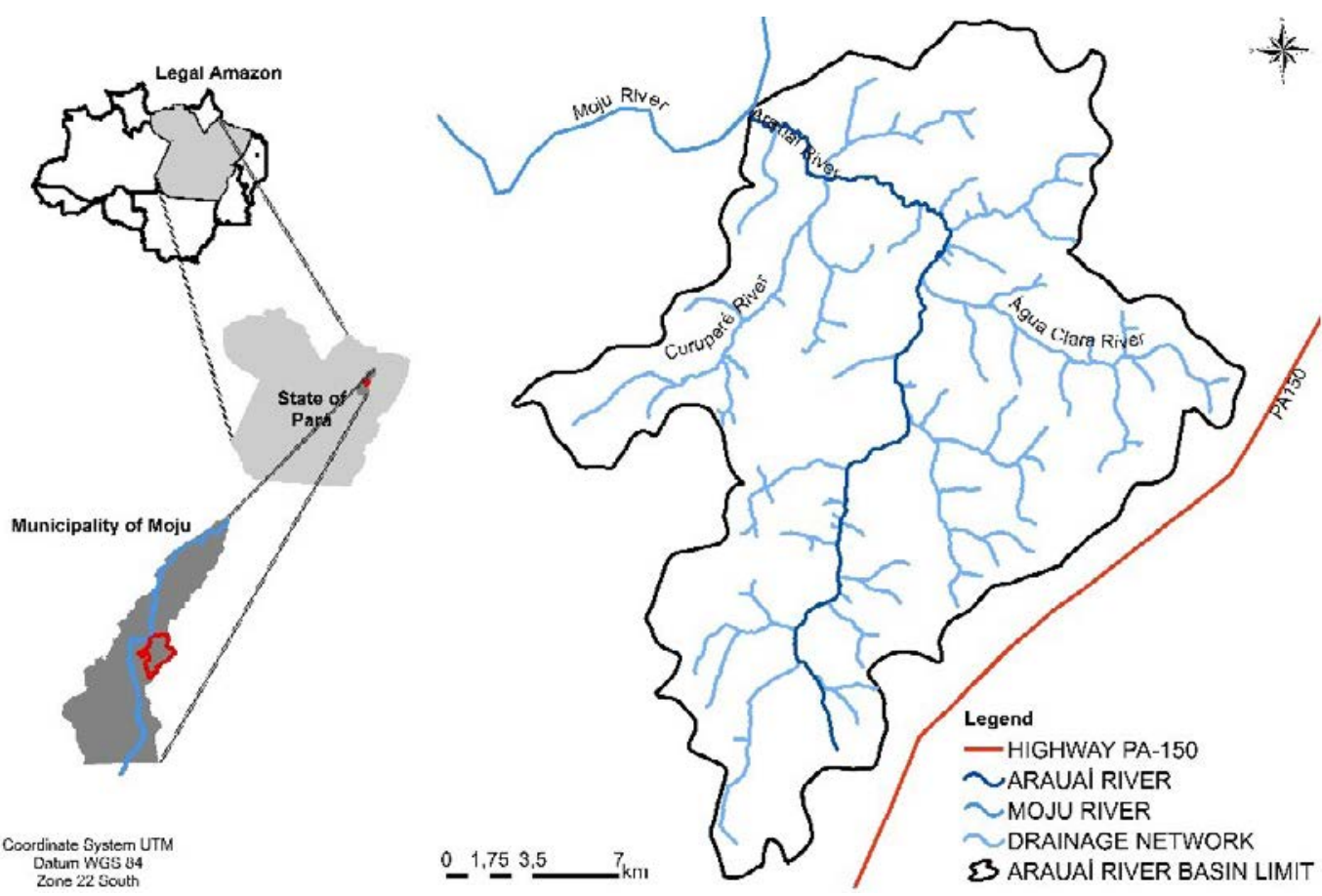

Figure 1. Location of Arauaí river basin, Moju, Pará.

\subsection{Digital processing}

The land cover and land use map was generated from the processing with ENVI software version 4.5, Landsat- 8 image, OLI sensor, orbit-point 224/062, and spatial resolution of $30 \mathrm{~m}$, acquired on August 8, 2016. The spectral bands were R (6) G (5) B (4) combined, and aggregated panchromatic band 8 for best spatial resolution $(15 \mathrm{~m})$.

It was applied supervised classification (Maximum Likelihood - MaxVer). Classification validation was obtained from an error matrix, where the field data with the classification was crossed, generating the Global Accuracy and Kappa Index calculation

(Hudson \& Ramm, 1987). The vector data were edited in the UTM (Universal Transverse Mercator) Coordinate System, WGS-84 datum, Zone 22S, in the ArcGIS 10.1 software.

\subsection{Multicriteria analysis}

The Weighted Linear Combination method was employed for aggregating the criteria. This method is one of the employed in multi-criteria analysis (Sartori et al., 2012; Valente et al., 2017; Voogd, 1983). The aggregation is done by multiplying each map (i.e. each cell or pixel) by its weight and subsequently summing the results. 


\subsection{Definition and weighting of criteria}

Five criteria were defined related to the biophysical aspect of the landscape and to the great contribution for the passive restoration of degraded or in process of degradation areas. The criteria were weighted taking into account extensive revisions of works produced in the area (Amiri et al., 2013; Chandio \& Matori, 2011; Geneletti \& Duren, 2008; Valente et al., 2017; Vettorazzi \& Valente, 2016), including extensive knowledge of the authors about the basin of the Arauaí river (Mateo, 1984; Perim \& Cocco, 2016). The subject of each test was normalized on a scale from 1.0 to 3.0. Values close to 1.0 indicate low priority for restoration, close to 2.0 are considered as medium priority, and values close to 3.0 are thematic assigned as high priority to passive restoration (Table 1).

Table 1. Weighting of priority criteria for passive restoration of Arauaí river basin, Moju, Pará.

\begin{tabular}{llc} 
Criterion & Classification & Weight \\
Natural Erosion & Very low & 1.0 \\
Vulnerability (NEV) & Low & 1.5 \\
& Middle & 2.0 \\
& High & 2.5 \\
Potential Cover and Land & Degraded Forest & 3.0 \\
Use for Passive Restoration & Secondary Vegetation & 2.5 \\
(PCPR) & Extensive pasture & 1.2 \\
& Intensive pasture & 1.0 \\
& $0-35 \mathrm{~m}$ & 3.0 \\
Proximity to the Primary & $35-100 \mathrm{~m}$ & 2.5 \\
Forest (Prox_PF) & $100-200 \mathrm{~m}$ & 2.0 \\
& $200-300 \mathrm{~m}$ & 1.5 \\
& $\geq 300 \mathrm{~m}$ & 1.0 \\
Forest Cover Deficit in & $00-20 \%$ & 1.0 \\
PPAs (FD_PPA) & $20-30 \%$ & 1.5 \\
& $40-40 \%$ & 2.0 \\
& $70-100 \%$ & 2.5 \\
& $0-10 \mathrm{~m}$ & 3.0 \\
\hline Highways (Dist_ROA) & $10-25 \mathrm{~m}$ & 1.0 \\
& $100-150 \mathrm{~m}$ & 1.2 \\
& $150-200 \mathrm{~m}$ & 1.5 \\
& $\geq 200 \mathrm{~m}$ & 2.0 \\
& & 2.2 \\
& & 2.5 \\
& & 3.0 \\
\hline
\end{tabular}

\subsubsection{Criterion: natural erosion vulnerability (NEV)}

For the elaboration of the NEV criterion, the methodology of Crepani et al. (2001) was used, considering the following themes: declivity, vegetation cover and land use, pedology, geology, and geomorphology (Table 2).
Table 2. Themes related to natural erosion vulnerability of the Arauaí river basin, Moju, Pará.

\begin{tabular}{|c|c|c|}
\hline Theme & Class & Weight \\
\hline \multirow{4}{*}{ Declivity } & $<2 \%$ & 1.0 \\
\hline & $2-6 \%$ & 1.5 \\
\hline & $6-20 \%$ & 2.0 \\
\hline & $20-50 \%$ & 2.5 \\
\hline \multirow{10}{*}{$\begin{array}{l}\text { Vegetation } \\
\text { Cover and } \\
\text { Land Use }\end{array}$} & Primary forest & 1.0 \\
\hline & Degraded forest & 1.1 \\
\hline & Secondary vegetation & 1.3 \\
\hline & Oil palm & 1.5 \\
\hline & Agriculture & 2.8 \\
\hline & Extensive pasture & 2.9 \\
\hline & Intensive pasture & 3.0 \\
\hline & Exposed soil & 2.5 \\
\hline & Campinarana & 2.6 \\
\hline & Water & 0.0 \\
\hline \multirow{3}{*}{ Pedology } & Dystrophic Yellow Latosol & 1.0 \\
\hline & $\begin{array}{l}\text { Hydromorphic Ferrihumiluvic } \\
\text { Spodosol }\end{array}$ & 2.0 \\
\hline & Dystrophic Plintosol Argilúvico & 3.0 \\
\hline Geology & Pleistocene Detrito-Lateritic Cover & 3.0 \\
\hline \multirow{3}{*}{ Geomorphology } & Retocado Inumado Pediplain & 1.0 \\
\hline & Plans Abaciados Inundation & 2.0 \\
\hline & Fluvial Terrace Plain & 3.0 \\
\hline
\end{tabular}

We used the SRTM/Topodata (scene 02S495) altimetry database, with spatial resolution of $30 \mathrm{~m}$, obtained from the vector grid of the National Institute of Space Research (INPE) database. This subject presents its values in percentage classified and weighted in five intervals.

\subsubsection{Vegetation cover and land use}

This theme was weighted according to the vegetation cover degree of the landscape unit, which consists of a protection factor against erosive processes. Environments with high density cover were assigned weights near 1.0 (representing stability), intermediate density weights to around 2.0 vegetation, and low-density assign weights close to 3.0 (representing instability).

2.4.1.3. Pedology (soil type), geology and geomorphology

These subjects were obtained from the database of the Brazilian Institute of Geography and Statistics (IBGE), on a 1:250,000 scale. Subject pedology was weighted according to its 
erosion resistance capacity (Mannigel et al., 2002). The sandier, the more susceptible to erosion and greater vulnerability.

In the geology theme, only one geological unit was found, represented by the Pleistocene Detrito-Lateritic Cover, which was assigned a 3.0 weight. This weight was assigned due to geological unit consisting mainly of sandy materials and that have come from intense agricultural activity.

On geomorphology, the values for vulnerability were weighted according to the type of relief, considering the morphometric parameters of the relief and drainage forms (Corvalán \& Garcia, 2011). Fluvial Terrace Plain class received higher weight (3.0) as they were areas of river valleys bordering water courses, partly flooded, and flat lands. On the other hand, Retoca do Inumado Pediplain class was attributed the lowest weight (1.0).

Each theme represents a thematic map and for each map a weight (values) was applied, being 2.5 for declivity, 3.0 for vegetation cover and land use, 2.2 for pedology, 1.3 for geomorphology, and 1.0 for geology. These weights represent the importance of each theme for the NEV criterion. The integration of these issues resulted in the natural vulnerability to erosion map.

\subsubsection{Criterion: potential vegetation cover and land use for passive restoration (PCPR)}

From the vegetation cover and land use map, we extracted and weighted the degraded forest, secondary vegetation, dirty and clean pasture classes, considered potential for passive restoration. Weights of 3.0 were applied to classes with a higher degree of vegetation cover, which indicated high resilience potential in relation to the other classes and high natural regeneration capacity. In contrast, classes of land use with little or no natural vegetation cover received weights close to 1.0 indicating that these classes are of low priority for passive restoration.

\subsubsection{Criterion: proximity to the primary forest (Prox_PF)}

In this criterion, we used polygons (shapefile) of the primary forest class and clean and dirty pasture classes. We selected the forest polygons above 10 ha and established a minimum distance of 35 meters-assuming that at this distance the seed dispersal is high and constant (Dias et al., 2014) - between the primary forest and the land use classes.

Distance was calculated using the Near 10.1 tool from the ArcGIS (ESRI, 2014), software resulting in a proximity map (distance) and the file was converted to raster format. As proposed by Reich \& Francelino (2012), 3.0 weights were assigned to close land use classes $(0-35 \mathrm{~m})$ from the primary forest and distant land use classes were assigned 1.0 weight.

\subsubsection{Criterion: forest cover deficit in PPAs (FD_PPA)}

We used the shapefile file drainage of Araiuaí River basin, available on the website of the Department of Environment and Sustainability of Pará (SEMAS-PA), in a 1:100,000 scale.

Only the PPAs of watercourses and springs were considered. The delimitation was accomplished to create a buffer zone from the regular bed of the watercourses. The area covered by the buffer was established in accordance with the Native Vegetation Protection Law, called the New Brazilian Forest Code Art. 4 (Law 12,727/2012). For the PPAs around springs were created buffers of $50 \mathrm{~m}$ at points located in forest areas and $15 \mathrm{~m}$ on those entered in consolidated areas that have suffered some kind of change in accordance with the established definition in Art. 61A, $\$ 5$ of the Law 12,727/2012.

After spatialization, the dissolve tool was used to correct overlapping PPAs along watercourses and springs, making it possible to measure the total area corresponding to the PPAs. The primary forest in the PPAs was cut, and then the forest area $\left(\mathrm{km}^{2}\right)$ and the primary forest deficit (\%) in the PPAs were calculated. The deficit was weighted according to the classification performed by Sparovek et al. (2011) adapted to the study area, applying a higher weight (3.0) in PPAs that presented a forest cover deficit of more than $70 \%$.

\subsubsection{Criterion: distance from roads and highways (Dist_ROA)}

In this criterion, the polygons (shapefile) of roads and highways and the PCPR criterion were used. Using the Near tool (ArcGIS 10.1 software), a distance map was generated between the road vectors and PCPR, adopting a maximum limit of $200 \mathrm{~m}$ distance from the road network (Francisco et al., 2008). We established that the greater the distance of the PCPR criterion in relation to roads and highways, the greater the priority (weight 3.0 ) of passive restoration.

\subsection{Aggregation of criteria}

Each criterion was represented by a map, which in turn, was weighted. We attributed a weight (value) 2.8 for the PCPR map; 2.7 for Prox_PF; 1.9 for FD_PPA; 1.1 for Dist_Roa; and 1.5 for the NEV map. These weights were applied according to the importance of each criterion in the indication of priority areas for passive restoration in the Arauaí river basin. The criteria maps were aggregated as shown in Equation 1 (Malczewski \& Rinner, 2015).

$\mathrm{AP}_{\text {passive }}=\left(\mathrm{PCPR}^{\star} \mathrm{p}+\right.$ Prox_PF ${ }^{\star} \mathrm{p}+\mathrm{FD}_{-} \mathrm{PPA}{ }^{\star} \mathrm{p}+$ Dist_ROA $\left.^{\star} \mathrm{p}+\mathrm{NEV}^{\star} \mathrm{p}\right)(1)$ 
Where $\mathrm{AP}_{\text {passive }}$ :areas for the passive restoration; PCPR: potential cover and land use for passive restoration map; Prox_PF: proximity to the primary forest map; FD_PPA: forest cover deficit in PPAs map; Prox_ROA: distance from roads and highways map; NEV: natural erosion vulnerability map; p: weight or importance value to passive restoration.

\section{RESULTS AND DISCUSSION}

\subsection{Vegetation cover and land use diagnosis}

The vegetation cover and land use map presented ten classes for the A rauaí river hasin (Fioure 2). Arrordino to the ronfusion
$49^{\circ} 1^{\circ} 0^{\circ} \mathrm{W} W$

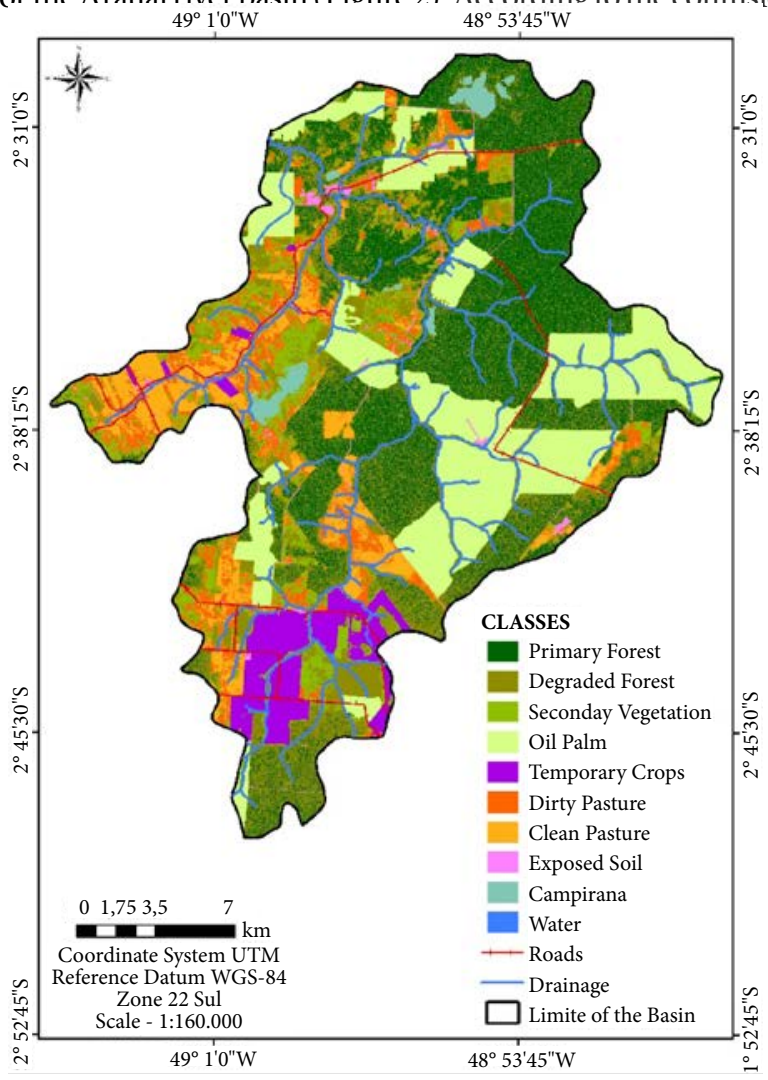

Figure 2. Vegetation cover and land use map of the Arauaí river basin, Moju, Pará.

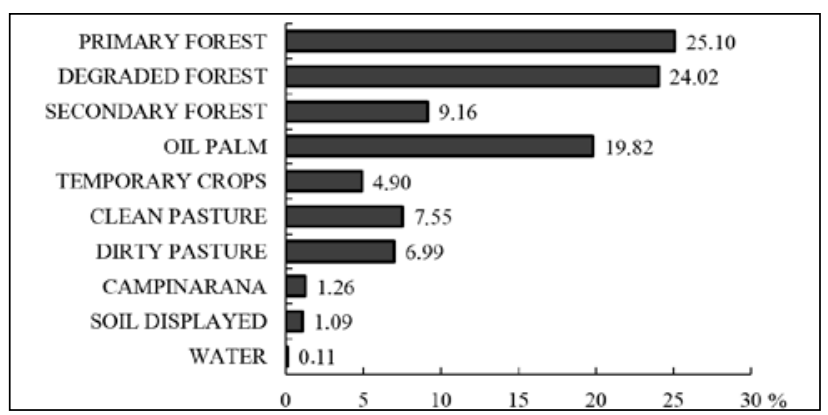

Figure 3. Quantification of land cover and land use classes of the Arauaí river basin, Moju, Pará. matrix report, $90.1 \%$ overall accuracy and a Kappa index value of 0.9 were attained for the 2016 classification-map. These values met the minimum accuracy requirements to be used for subsequent post-classification analyses (Wrublack et al., 2012).

Economic activities represented by pasture and agriculture guide the degree of occupation and land use in the region, occupying about $40 \%$ of the total area of the basin, as shown in Figure 3.

The remaining native forest (primary forest and degraded forest) occupies almost $50 \%$ of the Arauaí River basin. Degraded forest is a forest type in which most or all of the commercial timber has been removed by conventional logging. Almeida et al. (2020) reveal that there is an increase of $15 \%$ from 1991 to 2013 of degraded forest in the Moju region, due to the ongoing effects of fires and unregulated logging activities. Forest degradation leads to impoverishment of the forest in terms of biodiversity and carbon stocks, and it is thus important that it be evaluated. Secondary vegetation resulting from natural regeneration and the process of ecological succession in abandoned areas after cultivation, occupies $9.16 \%$. Arauaí river basin follows the deforestation rate of the Moju municipality, showing conversion of forests to agricultural areas (Almeida \& Vieira, 2014). In fact, dramatic increase of deforestation in Moju region from 1991 to 2013 leads to $50 \%$ of forest loss and reflects the substitution of this vegetation by expanding oil palm plantations and ranching operations (Almeida et al., 2020).

The dominant land use in the studied basin is oil palm, occupying $92.31 \mathrm{~km}^{2}$ (19.82\%). The oil palm crop still continues to rise economically, due to high demand for palm oil in the national and international markets. The dynamics established in this region public policies to encourage such culture causing significant changes in the landscape (Nahum \& Santos, 2016). As reported by Almeida et al. (2020), the palm oil producers in the eastern Amazon destroyed large areas of forests to expand plantations, which brought landscape changes such as increasing fragmentation, isolation and reduction in the area of forest remnants.

\subsection{Priority areas for passive restoration}

Analysis of priority areas identified $207.82 \mathrm{~km}^{2}$ of potential areas for passive restoration, with $66 \%$ having medium priority, followed by $16.35 \%$ and $15.15 \%$ with low and high priorities for passive restoration, respectively (Table 3). The modeled landscape scenario of the Arauaí river basin indicated a medium potential to apply the natural regeneration method associated to the presence of numerous fragments of degraded forest surrounded by secondary vegetation that contribute to seed dispersal of tree species. 
Table 3. Distribution of priority classes of passive restoration according to the multicriteria analysis used for the Arauaí river basin, Moju, Pará.

\begin{tabular}{lccc} 
Priority Class & Degree of Priority & Area $\left(\mathbf{k m}^{2}\right)$ & $\%$ \\
\hline Restrictions & - & 258.00 & - \\
\hline Very Low & $1.00-1.35$ & 0.09 & 0.04 \\
\hline Low & $1.35-1.75$ & 33.98 & 16.35 \\
\hline Medium & $1.75-2.25$ & 138.45 & 66.62 \\
\hline High & $2.25-2.65$ & 32.28 & 15.15 \\
Very Tall & $2.65-3.00$ & 3.02 & 1.45 \\
Total & - & 465.82 & 100 \\
\hline
\end{tabular}

In the passive restoration map (Figure 4), the restrictions represented $258 \mathrm{~km}^{2}$ of the Arauaí river basin. These restrictions represent areas that were not considered a priority for the passive restoration of forest cover. In the NEV criterion there were no restrictions. Primary forest classes, campinarana, oil palm cultivations, temporary crops, exposed soil, and water were considered restrictions on PCPR criteria Prox_PF and Dist_ROA. As for the FD_PPA criteria, we considered restrictions all map classes of vegetation cover and land use because the aim of restoring this criterion is only the track related to PPAs.

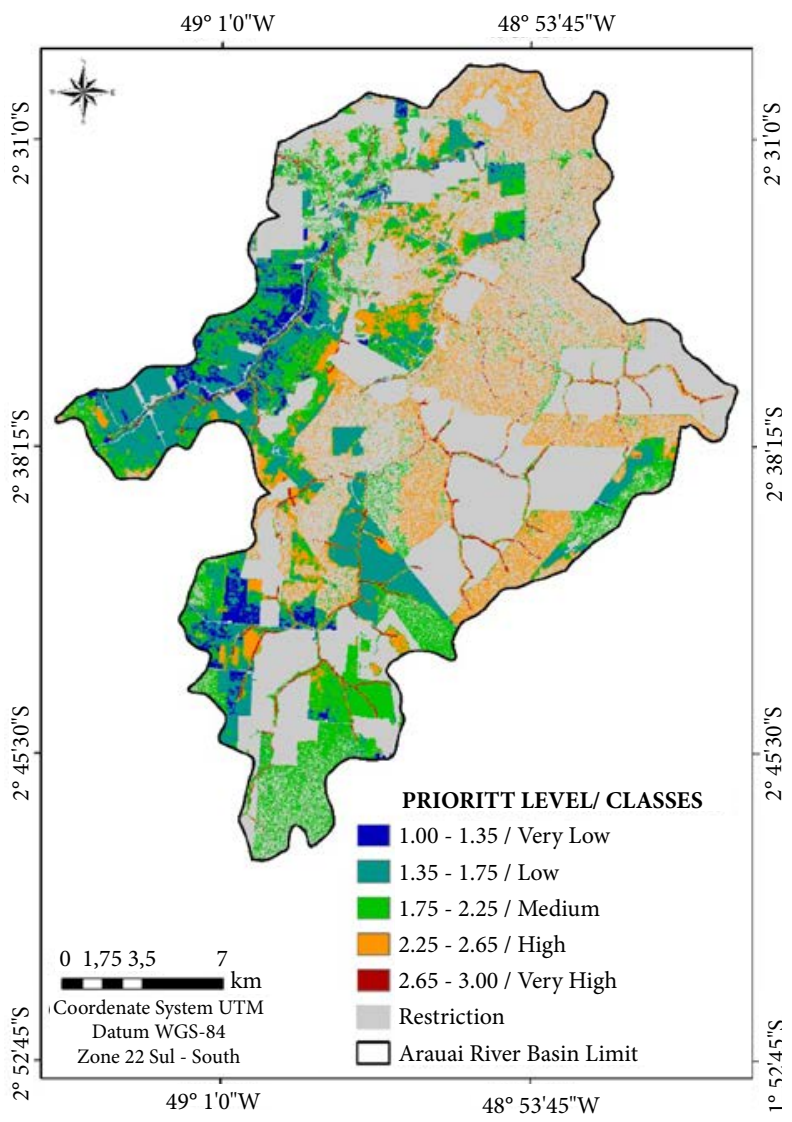

Figure 4. Map of priority areas for the passive restoration of the Arauaí river basin, Moju, Pará.

\subsubsection{Very low priority $(1.00-1.35)$}

Characterized by the dark blue color, this class occupied a small area of the basin, classified as very low natural vulnerability to erosion. In this area, fragments of secondary vegetation and dirty pasture are included, located more than $200 \mathrm{~m}$ away from the primary forests, therefore outside the PPA limit and distant $10 \mathrm{~m}$ to $25 \mathrm{~m}$ of roads and highways. These situations give this class a very low degree of priority because there is no influence of primary forests to seed rain, affecting the natural regeneration process.

\subsubsection{Low priority $(1.35-1.75)$}

This class is represented by the light blue color, presenting medium natural erosion vulnerability (NEV criterion). This class includes as potential land use and land cover for passive restoration (PCPR criterion) fragments of degraded forest, and secondary vegetation, clean and dirty pastures. Concerning the proximity of the passive potential areas for restoration to the primary forest (Prox_PF criterion), this class has $89.1 \%$ of the area $\left(29.45 \mathrm{~km}^{2}\right)$, between $0-35 \mathrm{~m}$, of primary forests. The criteria described above give this class a low priority. The FD_PPA and Prox_Roa criteria were not representative in this class.

\subsubsection{Medium priority (1.75 to 2.25 )}

The green color characterizes this class. Most of it presents natural erosion vulnerability (NEV) ranging from low to medium, corresponding to $77.02 \%\left(106.54 \mathrm{~km}^{2}\right)$. Regarding the PCPR criterion, a large part (40.29\%) is represented by fragments of degraded forests. The average degree of priority is also due to $98.58 \%$ of the potential areas for passive restoration being near seed source areas $(0-35 \mathrm{~m})$. The total PPA area in this class corresponds to $1.95 \mathrm{~km}^{2}$, and $1.58 \mathrm{~km}^{2}$ are $70-100 \%$ of deforested area. The roads and highways are beyond $200 \mathrm{~m}$ (64.12\%).

\subsubsection{High priority $(2.25-2.65)$}

Indicated by the orange color, this class presents high VNE (88.38\%). Degraded forest is the dominant vegetation cover, corresponding to $82.56 \%\left(17.93 \mathrm{~km}^{2}\right)$. The high degree of priority is also reinforced by the Prox_PF criterion, whose potential areas for passive restoration are very close $(0-35 \mathrm{~m})$ to the primary forest. Regarding the APP, this class has APPs of $3.86 \mathrm{~km}^{2}$, and $2.75 \mathrm{~km}^{2}(71.26 \%)$ corresponds to a forest deficit ranging between $70-100 \%$. Roads and highways also show a great distance $(\geq 200 \mathrm{~m})$ from the power areas to the passive restoration, representing about $88.66 \%\left(17.9 \mathrm{~km}^{2}\right)$ of this class. 


\subsubsection{Very High Priority (2.65 - 3.00)}

Represented by the red color, this class has low natural erosion vulnerability, presenting about $73.39 \%\left(1.74 \mathrm{~km}^{2}\right)$ of area occupied by degraded forest and potential areas for passive restoration, which are almost $100 \%$ close to the primary forest. The high priority of this class is also associated to $1.8 \mathrm{~km}^{2}$ of PPA in need of restoration and further to $1.96 \mathrm{~km}^{2}$ (89.97\%) of power areas which are distant from roads and highways ( $\geq 200 \mathrm{~m})$.

On the western side of the Arauaí river basin, there is a relative dominance of more unstable areas, presenting large areas occupied by pasture and agriculture, occupying $39.26 \%$ $\left(182.88 \mathrm{~km}^{2}\right)$ of the Arauaí river basin area. The deconstruction process of the structure of the protective plant cover directly contributes to the degradation of the landscape of the Arauaí basin since small soil cover provided by agricultural pastures and crops are not sufficient to protect and conserve soil characteristics (Fantinel \& Benedetti, 2016).

On the eastern side, there are reduced fragments of primary forest surrounded by fragments of degraded forest, suppressed by logging and fire practices, which modified the tree structure of the vegetation. This is due to the disorderly growth of the means of production, resulting in the availability of natural resources, compromising environmental services, and directly affecting biodiversity (Lees et al., 2015).

Finally, the Arauaí river basin shows the priority areas for passive restoration with the following characteristics. Areas with medium vulnerability to erosion, degraded forest sites and secondary vegetation, being close to native vegetation and distant from roads or highways, as well as the deficit of forest cover ranging from $0 \%$ to $40 \%$ in permanent preservation areas (PPAs). These features make it possible to implement a quick recovery without human intervention and the need for emergency recovery restoration projects.

The PPAs were those that obtained the highest restoration priority, as they are directly affected by changes in land use. The study of land use and land cover in the Arauaí river basin showed that agricultural occupations do not respect the legislation that protects the PPAs, which worsens the situation of environmental degradation observed in the basin in this study.

The criterion Prox_PF presented great relevance for the construction of the priorities map. This criterion, in conjunction with the DF_PPA criterion, allowed the definition of a large number of areas suitable for passive restoration.

The prioritization of areas in the basin in this study provided a better understanding of the restoration capacity and areas that can be retrieved by natural regeneration, considering the proximity of primary forest fragments larger than ten hectares. The regions of the basin where these fragments are distant from potential areas for passive restoration were associated with the lowest priority values (weight 1.0 ), and by contrast, the greater proximity of these fragments was associated with higher priority values (weight 3.0 ).

\section{CONCLUSIONS}

Application of the weighted linear combination multicriteria method has made it possible to allocate, in a simplified way, areas for the passive restoration in the Arauaí river basin and can be an alternative for decision-making in river basin restoration projects. Weighting of five biophysical criteria and their variables classified the Arauaí river basin as medium priority for the passive restoration method. The PPAs were those that obtained the highest restoration priority, as they are directly affected by changes in land use. The study of the land use and cover in the Arauaí river basin showed that this occupation does not respect the legislation that protects the PPAs, which worsens the situation of environmental degradation verified in the basin in this study.

The use of natural regeneration also plays an important role in the recovery of degraded primary forests by logging and fire since this basin has a high value for restoration.

\section{ACKNOWLEDGEMENTS}

The authors are grateful for the support and financial resources of the Conselho Nacional de Desenvolvimento Científico e Tecnológico (CNPq) for the granting of master's scholarships to the first author (CNPq 574008/2008-0) and of productivity for the second author (CNPq 308778/2017-0). To the Programa de Pós-Graduação em Ciências Biológicas - Botânica Tropical (PPGBOT) of the Universidade Federal Rural da Amazônia (UFRA), in partnership with the Museu Paraense Emilio Goeldi for the master's degree opportunity for Tatiane Camila Martins Silva, and to the reviewers of this article for their valuable recommendations.

\section{SUBMISSION STATUS}

Received: 26 Mar. 2018

Accepted: 1 Feb. 2019

Associate editor: Rodrigo Studart Corrêa

(D) 0000-0002-9422-2629

\section{CORRESPONDENCE TO}

\section{Tatiane Camila Martins Silva}

Museu Paraense Emilio Goeldi, Av. Perimetral, 1.901,

CEP 66040-170, Belém, PA, Brasil

e-mail: camilamartins258@gmail.com 


\section{REFERENCES}

Almeida AS, Vieira ICG. Centro de endemismo Belém: status da vegetação remanescente e desafios para a conservação da biodiversidade e restauração ecológica. Revista de Estudos Universitários 2010; 36: 95-111.

Almeida AS, Vieira ICG. Conflitos no uso da terra em áreas de preservação permanente em um polo de produção de biodiesel no estado do Pará. Revista Ambiente e Água 2014; 9(3): 477-487. 10.4136/ambi-agua.1410

Almeida AS, Vieira ICG, Ferraz SFB. Long-term assessment of oil palm expansion and landscape change in the eastern Brazilian Amazon. Land Use Policy 2020; 90: 104321. 10.1016/j. landusepol.2019.104321

Amiri MJ, Mahiny AS, Hosseini SM, Jalali SG, Ezadkhasty Z, Karami SH. OWA analysis for ecological capability assessment in watersheds. International Journal of Environmental Research 2013; 7(1): 241-254.

Brasil. Ministério do Meio Ambiente. Plano Nacional de Recuperação da Vegetação Nativa: Planaveg [Internet]. Brasília, DF; 2017 [cited 2017 Nov. 16]. Available from: http://bit.ly/33nFkbo

Chandio IA, Matori ANB. GIS-based multi-criteria decision analysis of land suitability for hillside development. International Journal of Environmental Science and Development 2011; 2(6): 469-473. 10.7763/IJESD.2011.V2.171

Chazdon RL. Beyond deforestation: restoring forests and ecosystem services on degraded lands. Science 2008; 320: 1458-1460. 10.1126/ science. 1155365

Chazdon RL, Laestadius L. Forest and landscape restoration: toward a shared vision and vocabulary. American Journal of Botany 2016; 103(11): 1869-1871. 10.3732/ajb.1600294

Corvalán SB, Garcia GJ. Avaliação ambiental da APA Corumbatai segundo critérios de erodibilidade do solo e cobertura vegetal. Geociências 2011; 30(2): 269-283.

Crepani E, Medeiros JS, Hernandez Filho P, Florenzano TG, Duarte $\mathrm{V}$, Barbosa CCF. Sensoriamento remoto e geoprocessamento aplicado ao zoneamento ecológico-econômico e ao ordenamento territorial. São José dos Campos: Instituto Nacional de Pesquisas Espaciais; 2001.

Dias CR, Umetsu F, Breier TB. Contribuição dos poleiros artificiais na dispersão de sementes e sua aplicação na restauração florestal. Ciência Florestal 2014; 24(2): 501-507. 10.5902/1980509814590

Environmental Systems Research Institute - ESRI. ArcGIS: sistema de informação geográfica para área de trabalho de computador, versão 10.1 [Internet]. 2014 [cited 2017 Sept. 1]. Available from: https:// www.arcgis.com/features/

Fantinel RA, Benedetti ACP. Avaliação dos fatores influentes na vulnerabilidade à erosão do solo por meio de decisão multicritério e de técnicas de geoprocessamento no município de Piratini - RS. Ciência e Natureza 2016; 38(1): 156-163. 10.5902/2179460X19783

Francisco CES, Coelho RM, Torres RB, Adami SF. Análise multicriterial na seleção de bacia hidrográfica para recuperação ambiental. Ciência Florestal 2008; 18(1): 1-13. 10.5902/19805098506

Geneletti D, Duren IV. Protected area zoning for conservation and use: a combination of spatial multicriterial and multiobjective evaluation. Landscape and Urban Planning 2008; 85(2): 97-110. 10.1016/j.landurbplan.2007.10.004

Guerrero AC, Rocha PLB. Passive restoration in biodiversity hotspots: consequences for an Atlantic rainforest lizard taxocene. Biotropica 2010; 42(3): 379-387. 10.1111/j.1744-7429.2009.00584.x

Holl KD, Aide TM. When and where to actively restore ecosystems? Forest Ecology and Management 2011; 261: 1558-1563. 10.1016/j. foreco.2010.07.004

Hudson WD, Ramm CW. Correct formulation of the kappa coefficient of agreement. Photogrammetric Engineering and Remote Sensing 1987; 53(4): 421-422.

Instituto de Desenvolvimento Econômico, Social e Ambiental do Pará - IDESP. Diagnóstico da gestão ambiental dos municípios paraenses: relatório técnico. Belém: Imazon; 2013.

Instituto Nacional de Pesquisas Espaciais - INPE. Dados municipais do levantamento de informações de uso e cobertura da terra na Amazônia: TerraClass 2014 [Internet]. 2014 [cited 2017 June 16]. Available from: http://bit.ly/33rv81F

Lees AC, Moura NG, Almeida AS, Vieira ICG. Poor prospects for avian biodiversity in Amazonian oil palm. PLoS ONE 2015; 10(5): e0122432. 10.1371/journal.pone.0122432

Malczewski J, Rinner C. Multicriteria decision analysis in geographic information science. New York: Springer; 2015.

Mannigel AR, Carvalho MP, Moreti D, Medeiros LR. Fator erodibilidade e tolerância de perda dos solos do estado de São Paulo. Acta Scientiarum Agronomy 2002; 24: 1335-1340. 10.4025/ actasciagron.v24i0.2374

Mateo J. Apuntes de geografia de los paisajes. Habana: Universitaria; 1984.

Nahum JS, Santos CB. A dendeicultura na Amazônia paraense. Geousp: Espaço e Tempo 2016; 20(2): 281-294.

Orsi F, Geneletti D. Identifying priority areas for forest landscape restoration in Chiapas (Mexico): an operational approach combining ecological and socioeconomic criteria. Landscape and Urban Planning 2010; 94(1): 20-30.

Perim MA, Cocco MDA. Efeito das transformações antrópicas às margens do rio Una, Taubaté, São Paulo, Brasil. Ambiente \& Água 2016; 11(5): 1163-1171. 10.4136/ambi-agua.1918.

Ramalho Filho A, Motta PEF, Naime UJ, Goncalves AO, Teixeira WG. Zoneamento agroecológico para a cultura da palma de óleo nas áreas desmatadas da Amazônia Legal. In: Ramalho Filho A, Motta PEF, Freitas PL, Teixeira WG. Zoneamento agroecológico, produção e manejo para a cultura da palma de óleo na Amazônia. Rio de Janeiro: Embrapa Solos, 2010. p. 57-68.

Reich M, Francelino MR. Avaliação do potencial de recuperação de áreas alteradas em áreas de proteção permanente de cursos d'água no município de Rio Branco, Acre. Boletim Museu Paraense Emílio Goeldi Ciências Naturais 2012; 7(2): 157-168.

Sartori AAC, Silva RFB, Zimback CRL. Combinação linear ponderada na definição de áreas prioritárias à conectividade entre fragmentos florestais em ambiente SIG. Revista Árvore 2012; 36(6): 1079-1090. 10.1590/S0100-67622012000600009 
Silva TCM, Vieira ICG, Almeida AS. Irregularidades em áreas naturais protegidas na bacia do rio Arauaí, Moju, Pará. Revista GeoAmazônia 2016; 4(8): 93-106.

Sparovek G, Barreto A, Klug I, Papp L, Lino J. A revisão do Código Florestal Brasileiro. Novos Estudos Cebrap 2011; (89): 111-135. 10.1590/S0101-33002011000100007

Toledo PM, Vieira ICG, Jardim MAG, Rocha EJP, Coelho AS. A Amazônia em tempo de transformações e desafios: uma visão a partir da Pós-Graduação em Ciências Ambientais. In: Vieira ICG, Jardim MAG, Rocha EJP, editors. Amazônia em tempo: estudos climáticos e socioambientais. Belém: Universidade Federal do Pará: Museu Paraense Emílio Goeldi; 2015. p. 9-20.
Valente RA, Petean FCS, Vettorazzi CA. Multicriteria decision analysis for prioritizing areas for forest restoration. Cerne 2017; 23(1): 53-60. 10.1590/01047760201723012258

Vettorazzi CA, Valente RA. Priority areas for forest restoration aiming at the conservation of water resources. Ecological Engineering 2016; 94: 255-267. 10.1016/j.ecoleng.2016.05.069

Voogd H. Multicriteria evaluation for urban and regional planning. London: Pion; 1983.

Wrublack SC, Mercante E, Vilas Boas MA. Utilização de técnicas de geoprocessamento para caracterização de áreas aptas à irrigação por gotejamento no município de Salto do Lontra - Paraná. Revista de Estudos Ambientais 2012; 14(2): 6-13. 10.7867/1983-1501.2012v1 4n2p6-13 